\title{
KARAKTERISTIK INFORMASI TERKAIT CARA PENGGUNAAN METERED-DOSE INHALER DENGAN SPACER YANG MENGANDUNG KOMBINASI BETA-2 AGONIS DAN KORTIKOSTEROID OLEH APOTEKER DI APOTEK WILAYAH SURABAYA TIMUR
}

\author{
Submitted : 5 Februari 2018 \\ Edited : 7 Mei 2018 \\ Accepted : 17 Mei 2018 \\ Amelia Lorensia ${ }^{1}$, Doddy de Queljoe $^{1}$, Yessica Valensia ${ }^{2}$ \\ ${ }^{1}$ Departement of Clinical-Community Pharmacy, Faculty of Pharmacy, Surabaya of University \\ (Universitas Surabaya (UBAYA)) \\ ${ }^{2}$ Postgraduate Student of Bachelor of Pharmacy Science, Faculty of Pharmacy, Surabaya of \\ University (Universitas Surabaya (UBAYA)) \\ Email : amelia.lorensia@gmail.com; amelia.lorensia@staff.ubaya.ac.id
}

\begin{abstract}
Treatment of respiratory disorders using a metered-dose inhaler (MDI) with spacer becomes one of the important points. Pharmacists at pharmacies are the final key in therapy to ascertain how the use of inhalation tools is correct. This study aims to determine the completeness of each step of information on how to use MDI with spacer given by pharmacists at pharmacies in East Surabaya. The research design used is cross-sectional study with the subject of research is pharmacist in pharmacy. The research variable is the explanation of how to use MDI inhaler with spacer. An assessment method of 8 steps on how to use MDI with spacer and each number gets a value. Research subjects were 22 pharmacists. Most pharmacists describe each step orally by using the tool directly, ie at step: $1 a(77.27 \%), 1 b(77.27 \%), 2$ (81.81\%), 3 (31.81\%) , $4 a(59.09 \%), 4 b$ (13.63\%), 5a (100\%), $5 b$ (63.63\%), 6a (90.90\%), 6b (40.90\%), 8a (9,09\%), and $8 b(9.09 \%)$. Most of the pharmacists explain verbally with a demonstration tool but only one pharmacist can explain all the steps completely. Therefore, pharmacists need to improve IEC services related to the use of MDI with a spacer for respiratory treatment.
\end{abstract}

Keywords : information on how to use inhaler, Metered-Dose Inhaler (MDI), spacer, pharmacist, pharmacy

\section{PENDAHULUAN}

PPOK (Penyakit Paru Obstruksi Kronis) merupakan salah satu masalah mayor di dunia. Menurut survei nasional, prevalensi orang dengan gejala obstruksi aliran udara kronis dapat melebihi 24 juta $^{(1)}$. Komplikasi PPOK dapat berupa keterbatasan aktivitas pada pasien PPOK, penurunan berat badan, peningkatan risiko penyakit kardiovaskular, osteoporosis dan depresi. PPOK juga menyebabkan peningkatan biaya langsung hingga \$18 milyar dan biaya tidak langsung sebesar $\$ 14,1$ milyar dalam penanggulangan PPOK di Eropa ${ }^{(2)}$.

PPOK dapat dicegah dan diobati dengan pengobatan yang tepat dan efektif. Pengobatan PPOK dapat dibedakan menjadi terapi untuk pemeliharaan pada PPOK stabil dan terapi eksaserbasi akut ${ }^{(3)}$. Glukokortikoid merupakan golongan obat yang digunakan dalam kondisi stabil maupun eksaserbasi dalam terapi PPOK. Glukokortikoid berperan dalam kaskade inflamasi, meskipun efek kortikosteroid pada PPOK lebih kecil dibandingkan dengan asma. Data suatu studi dengan jumlah pasien yang besar, menunjukkan bahwa kortikosteroid inhalasi dapat menghasilkan peningkatan kecil dalam post-bronkodilator $\mathrm{FEV}_{1}$ (forced expiratory volume in 1 second) dan sedikit penurunan dalam reaktivitas bronkial pada PPOK stabil ${ }^{(4)}$. Terapi rutin dengan kortikosteroid inhalasi dapat memperbaiki gejala, fungsi paru, kualitas hidup, dan mengurangi frekuensi dari eksaserbasi pasien PPOK dengan prediksi $\mathrm{FEV}_{1}<60 \%$. Penggunaan golongan kortikosteroid sering dikombinasi dengan golongan beta agonis untuk lebih meningkatkan efektifitas dan menurunkan efek samping dibandingkan penggunaan tunggal ${ }^{(3)}$. 
Pengobatan PPOK lebih disarankan melalui inhalasi(3). Inhaler merupakan alat yang digunakan untuk pemberian obat secara inhalasi. Sistem pengiriman inhaler merupakan bentuk penting dari perangkat pemberian obat dalam pengobatan, karena memiliki keuntungan pemberian obat langsung ke sistem pernapasan dan efek samping yang lebih sedikit(5). Setiap jenis inhaler memiliki petunjuk penggunaan yang berbeda-beda dan membutuhkan cara yang berbeda pula dalam penanganannya. Penggunaan perangkat inhaler memerlukan serangkaian langkah-langkah yang perlu dilakukan dengan benar, sehingga kegagalan untuk melakukan satu atau lebih langkah dengan benar dapat mengurangi keefektifan obat dan keamanan obat. Hal ini menyebabkan meningkatnya kesalahan pasien dalam menggunakan alat inhalasi yang sebenarnya dirancang untuk meningkatkan kemudahan penggunaan dalam memberikan efek yang optimal(6). Hal ini menjadi penyebab utama perawatan sub-optimal(5), sehingga penggunaan inhaler menjadi relatif lebih mahal, jika tidak digunakan dengan benar. Penggunaan inhaler pada pasien PPOK yang efektif hanya dapat dicapai bila pasien merasa nyaman untuk menggunakan inhalasinya dengan benar. Inhaler yang paling banyak digunakan adalah jenis MDI (metered-dose inhaler).

Penggunaan kortikosteroid dalam sediaan MDI yang tidak tepat dapat berisiko menyebabkan pneumonia(7), candidiasis orofaringeal, horse voice, dan skin bruising(8). Perangkat spacer dirancang untuk mengatasi kesulitan dialami saat menggunakan MDI dan yang tersedia dalam berbagai bentuk dan ukuran. Spacer memiliki sebuah holding chamber dan one-way valve (katup satu arah) yang terbuka selama inspirasi dan menutup selama ekspirasi, untuk mencegah kerugian obat disebabkan oleh koordinasi yang buruk antara aktuasi dari MDI dan inspirasi. Partikel yang lebih besar yang tidak akan mencapai paru-paru tetap dalam spacer, sehingga secara signifikan mengurangi pengendapan obat dalam orofaring sehingga mengurangi adverse $\operatorname{effect}(9,10)$.

Pasien yang menggunakan MDI standar tanpa spacer, kegagalan mengkoordinasikan inspirasi dengan aktuasi telah terbukti berakibat pada menurunnya deposisi paru dari obat. Suatu penelitian pada pasien asma yang juga menggunakan inhaler dalam terapi, menunjukkan bahwa penggunaan yang tidak benar dari kortikosteroid MDI inhalasi menyebabkan kontrol asma menurun sehingga membutuhkan peningkatan penggunaan reliever, peningkatan penggunaan pelayanan medis darurat, memburuknya asma dan tingkat ketidakstabilan asma yang lebih tinggi (10). Penggunaan spacer membantu mengatasi masalah inspirasi dari MDI. Namun, obat tetap diberikan untuk waktu yang singkat saja, jadi jika pasien gagal untuk mengambil setiap dosis tanpa penundaan segera saat menggunakan spacer, sebagian dosis akan terdeposit pada permukaan bagian dalam spacer dan akan hilang(10).

Teknik inhalasi pada terapi pasien PPOK masih kurang, sehingga pada praktek kesehariannya peran farmasi komunitas di apotek akan sangat membantu secara signifikan dalam edukasi teknik inhalasi. Hubungan antara pasien dan apoteker, dapat membantu pengobatan yang optimal bagi pasien dalam memahami terapi obat, mengontrol gejala asma, dan informasi penggunaan inhaler(11). Pengetahuan pasien teknik inhaler yang benar adalah penting dalam pengobatan penyakit paru maka apoteker membutuhkan pendidikan yang tepat dalam pemerintahan diri yang benar obat inhalasi, karena merupakan tanggung jawab apoteker untuk memastikan bahwa pasien tahu bagaimana membuat penggunaan terbaik dari pengobatan mereka(5). Apoteker yang berada di apotek merupakan kunci akhir dalam terapi sebelum pasien melakukan terapi inhalasi sendiri dan karena itu apoteker memiliki kewajiban untuk memastikan apabila cara penggunaan alat inhalasi yang pasien gunakan adalah benar, sehingga dapat dicapai hasil yang diinginkan. Di Indonesia, dalam Permenkes No. 35 tahun 2014,(12) tentang Standar Pelayanan Kefarmasian di Apotek tercantum bahwa apoteker harus memberikan konseling dan informasi obat, terutama kepada pasien dengan penyakit kronis, seperti PPOK dan pasien yang menggunakan obat dengan instruksi khusus atau alat khusus seperti inhaler. Namun, banyak apoteker kurang memiliki keterampilan yang diperlukan secara memadai untuk menunjukkan teknik penggunaan inhaler dengan benar(13,14). Di Indonesia penelitian serupa juga menunjukkan bahwa apoteker harus lebih mempersiapkan diri dalam memberikan informasi cara penggunaan alkes termasuk inhaler pada pasien $(15,16,17)$. Oleh karena itu, tujuan penelitian ini adalah mengetahui kelengkapan tiap langkah dari informasi cara penggunaan MDI dengan spacer yang diberikan oleh apoteker di apotek di Surabaya Timur.

\section{METODE PENELITIAN \\ Desain Penelitian}

Desain penelitian yang digunakan adalah penelitian observasional, dengan metode 
cross-sectional study. Data dikumpulkan dari apotek-apotek yang ada di Surabaya. Proses pengambilan data pada penelitian ini dilakukan pada bulan Agustus 2014 Desember 2015. Variabel penelitian ini terdiri dari informasi penjelasan cara penggunaan inhaler MDI dengan spacer. Kehadiran apoteker di apotek dinilai dari seberapa banyak apoteker berada di apotek (stand-by), berdasarkan wawancara dengan apoteker/tenaga kefarmasian. Apoteker disebut stand-by apabila berada di apotek setiap hari, sesuai dengan PP No.51 tahun $2009{ }^{(18)}$.
Informasi penjelasan cara penggunaan MDI dengan spacer adalah informasi yang diberikan oleh apoteker di apotek mengenai cara penggunaan MDI yang mengandung kombinasi kortikosteroid dan beta-2 agonis (Seretide®MDI) dengan spacer (Aerocamber@ dengan mask) kepada peneliti pada saat wawancara di apotek. Kelengkapan penjelasan penggunaan sediaan controller MDI dengan spacer yang dicocokkan dengan langkah penggunaan sediaan controller MDI dengan spacer yang terdapat dalam checklist (Table 1) ${ }^{(19)}$.

Tabel 1. Score Penilaian Kelengkapan Cara Penggunaan MDI dengan Spacer

\begin{tabular}{|c|c|c|c|}
\hline No & Langkah & Sub-langkah & Score \\
\hline \multirow[t]{2}{*}{1} & \multirow{2}{*}{$\begin{array}{l}\text { Lepaskan tutup MDI. Kemudian kocok } \\
\text { MDI ke atas dan ke bawah. }\end{array}$} & Lepaskan tutup MDI & 1 \\
\hline & & Kocok MDI ke atas dan ke bawah & 1 \\
\hline 2 & \multicolumn{2}{|l|}{$\begin{array}{l}\text { Masukkan MDI dalam lubang di belakang } \\
\text { spacer }\end{array}$} & 1 \\
\hline 3 & Ambil posisi duduk tegak & & 1 \\
\hline \multirow[t]{4}{*}{4} & \multirow{4}{*}{$\begin{array}{l}\text { Masukkan masker di dalam mulut dan } \\
\text { hidung. Tekan masker pada wajah. } \\
\text { Pastikan tidak ada jarak (gap) antara } \\
\text { wajahnya dan masker. Pegang masker } \\
\text { pada wajah dengan satu tangan. Dan } \\
\text { tangan lain memegang spacer, dengan jari } \\
\text { Anda di atas tabung canister MDI. }\end{array}$} & $\begin{array}{l}\text { Masukkan masker di dalam mulut dan } \\
\text { hidung }\end{array}$ & 1 \\
\hline & & $\begin{array}{l}\text { Tekan masker pada wajah, pastikan } \\
\text { tidak ada jarak (gap) antara wajah } \\
\text { dengan masker. }\end{array}$ & 1 \\
\hline & & $\begin{array}{l}\text { Pegang masker pada wajah dengan } \\
\text { satu tangan. }\end{array}$ & 1 \\
\hline & & $\begin{array}{l}\text { Dan tangan lain memegang spacer, } \\
\text { dengan jari Anda di atas tabung } \\
\text { canister MDI. }\end{array}$ & 1 \\
\hline \multirow[t]{2}{*}{5} & \multirow{2}{*}{$\begin{array}{l}\text { Tekan tabung canister MDI ke bawah } \\
\text { untuk menyemprotkan satu semprotan ke } \\
\text { dalam spacer. }\end{array}$} & $\begin{array}{l}\text { Tekan tabung canister MDI ke bawah } \\
\text { untuk menyemprotkan satu semprotan }\end{array}$ & 1 \\
\hline & & Satu semprotan ke dalam spacer & 1 \\
\hline \multirow[t]{2}{*}{6} & \multirow{2}{*}{$\begin{array}{l}\text { Bernafaslah dengan menarik dan } \\
\text { menghembuskan udara melalui mulut } \\
\text { beberapa kali ( } \pm 6 \text { kali) }\end{array}$} & $\begin{array}{l}\text { Bernafaslah dengan menarik dan } \\
\text { menghembuskan udara }\end{array}$ & 1 \\
\hline & & Beberapa kali ( \pm 6 kali) & 1 \\
\hline \multirow[t]{2}{*}{7} & \multirow{2}{*}{$\begin{array}{l}\text { Jika dibutuhkan lebih dari satu semprotan } \\
\text { obat, ulangi langkah } 5-7 \text {. Jangan } \\
\text { menyemprotkan lebih dari satu semprotan } \\
\text { dalam satu waktu ke dalam spacer. }\end{array}$} & $\begin{array}{l}\text { Jika dibutuhkan lebih dari satu } \\
\text { semprotan obat, ulangi langkah } 5-7\end{array}$ & 1 \\
\hline & & $\begin{array}{l}\text { Jangan menyemprotkan lebih dari satu } \\
\text { semprotan dalam satu waktu ke dalam } \\
\text { spacer. }\end{array}$ & 1 \\
\hline \multirow[t]{2}{*}{8} & \multirow{2}{*}{$\begin{array}{l}\text { Bilas mulut dengan air dan keluarkan air } \\
\text { tersebut (jangan ditelan). Membilas mulut } \\
\text { dapat mengurangi beberapa efek samping, } \\
\text { seperti lapisan putih di lidah Anda } \\
\text { (infeksi jamur yang disebut thrust) atau } \\
\text { sakit tenggorokan. }\end{array}$} & $\begin{array}{l}\text { Bilas mulut dengan air dan keluarkan } \\
\text { air tersebut. }\end{array}$ & 1 \\
\hline & & $\begin{array}{l}\text { Membilas mulut dapat mengurangi } \\
\text { beberapa efek samping, seperti lapisan } \\
\text { putih di lidah atau sakit tenggorokan }\end{array}$ & 1 \\
\hline
\end{tabular}


Informasi tambahan yang digunakan apoteker dalam menjelaskan penggunaan MDI dengan spacer adalah penjelasan yang diberikan apoteker saat diwawancarai meliputi : Informasi tambahan yang digunakan apoteker dalam memberikan penjelasan informasi cara penggunaan MDI dengan spacer, berupa informasi tambahan apa yang digunakan apoteker pada saat memberikan penjelasan cara penggunaan MDI dengan spacer, (seperti: orang lain/ rekan lain di apotek, brosur obat dari Seretide ${ }^{\circledR M D I}$ dan/atau brosur alat Aerocamber ${ }^{\circledR}$ (dengan mask), dan internet/ pustaka lain. Serta bagaimana cara mendapatkan informasi tambahan bila apoteker membutuhkan info lebih lanjut mengenai produk ini. Informasi kesediaan obat dan alat di apotek tempat apoteker melakukan praktek kefarmasian. Apabila obat/alat tersedia di apotek, maka peneliti menanyakan mengenai: (i) Seberapa sering apoteker melayani barang itu ?; (ii) Siapa yang biasanya melayani ?; dan (iii) Siapa yang biasanya melakukan konseling?. Apabila obat/alat tidak tersedia di apotek, maka peneliti menanyakan apakah apotek pernah menjual produk tersebut.

\section{Populasi dan Sampel}

Populasi dalam penelitian ini adalah apoteker yang melakukan praktek kefarmasian di apotek di Surabaya. Populasi target dalam penelitian ini adalah apoteker yang dapat ditemui di apotek di wilayah Kota Surabaya. Populasi terjangkau dalam penelitian ini adalah apoteker yang dapat ditemui di apotek di Surabaya Timur dengan kriteria : Apotek tempat apoteker bekerja, memiliki ijin tempat praktek dan aktif melakukan pekerjaan kefarmasian (buka hampir setiap hari). Apotek tempat apoteker bekerja, melayani obat bagi umum dan bukan hanya melayani klinik tertentu (contoh: apotek yang hanya melayani peresepan oleh dokter praktek tertentu; apoteker yang hanya melayani obat dari klinik kecantikan). Apoteker stand-by di apotek tempat dia bekerja. Apoteker tidak bekerja di apotek yang merupakan franchise.

Sampel dalam penelitian ini adalah apoteker yang dapat ditemui di apotek di Surabaya Timur yang memenuhi kriteria populasi terjangkau, yang bersedia memberikan penjelasan cara penggunaan inhaler MDI dengan spacer pada peneliti dan menandatangani inform consent. Satu apoteker mewakili satu apotek di Surabaya Timur. Pada penelitian ini pengambilan sampel dilakukan dengan metode non-random sampling dengan menggunakan teknik purposive sampling di mana pengambilan sampel dipertimbangkan berdasarkan ketersediaan apoteker mengisi informed consent.
Studi pendahuluan di lapangan terhadap semua apotek yang terdapat di seluruh wilayah Kota Surabaya, berdasarkan data Dinas Kesehatan (2013). Jumlah apotek yang terdaftar sebanyak 875 apotek dan terdapat 743 apotek aktif (tanpa apotek franchise yang berada di mall di Surabaya). Berdasarkan data penelitian sebelumnya ${ }^{(15,16,17)}$, menunjukkan bahwa wilayah Surabaya Timur memiliki jumlah apotek yang terdaftar yang paling banyak dibandingkan wilayah Surabaya lainnya (Timur, Selatan, Barat, dan Pusat). Kemudian dilakukan studi pendahuluan oleh peneliti pada Bulan Oktober 2014 sampai dengan Januari 2015, jumlah populasi terjangkau diperkirakan sebanyak 122 apoteker, dengan confidence level sebesar 95\% dan margin of error sebesar 5, maka berdasarkan rumus di bawah ini .

$$
\mathbf{n}=\frac{\text { p.q.N. } \cdot Z^{2}}{\mathrm{~N} \cdot \mathbf{d}^{2}+\mathbf{p} \cdot \mathbf{q} \cdot \mathbf{Z}^{2}}
$$

Bila:

$\mathrm{p}=\mathrm{q}=0,5=$ Proporsi untuk sifat tertentu yang diperkirakan pada populasi

$\mathrm{N}=$ Besar populasi terjangkau $=122$

$\mathrm{d}=0,1=$ Derajat ketepatan yang diinginkan

$\mathrm{Z}=1,96=$ Standart deviasi normal sesuai dengan derajat kemaknaan $95 \%$

$\mathrm{n}=$ Besarnya sampel

Jadi banyak apotek yang digunakan (n) adalah sebanyak 53,74 54 apotek.

\section{Metode Pengambilan Data}

Langkah-langkah yang dilakukan dalam pengambilan data:

a. Validasi checklist dilakukan dengan menyamakan persepsi arti dan penilaian dari setiap langkah pada cheklist antar peer-reviewer yang merupakan calon interrater dalam pelaksanaan penelitian.

b. Pembagian informed consent di semua apotek di Wilayah Surabaya Timur. Satu apoteker mewakili satu apotek. Pada saat mengunjungi setiap apotek yang dipilih sebagai tempat penelitian, peneliti meminta apoteker yang melakukan praktek kefarmasian di apotek tersebut untuk mengisi pada lembar informed consent, yang menandakan apoteker bersedia diwawancarai dan terlibat dalam penelitian.

c. Pengambilan data. Di tiap apotek terpilih, peneliti akan bertanya untuk bertemu dengan apoteker terlebih dahulu, apabila apoteker tidak di tempat atau berhalangan, maka peneliti akan menanyakan kapan bisa bertemu dengan apoteker atau meminta untuk dibuatkan janji bertemu. Namun apabila apoteker menolak/ tidak bisa ditemui maka peneliti akan mencari 
apoteker dari apotek lainnya. Peneliti akan menjelaskan identitas dan maksud kedatangan sebenarnya. Apoteker yang bersedia akan diminta menjelaskan cara menggunakan sediaan Seretide $\AA$ MDI dengan spacer yang benar, dengan berkata: "Bersediakan bapak/ibu menjelaskan kepada saya cara pakai alat ini denganpenggunaan obat ini sehari sekali dan setiap kali pakai sebanyak satu semprotan." Peneliti menyerahkan Seretide ${ }^{\circledR}$ MDI dalam kotak primer dan spacer Aerochamber ${ }^{\circledR}$ dalam kotak kepada apoteker (Gambar 1 dan Gambar 2).

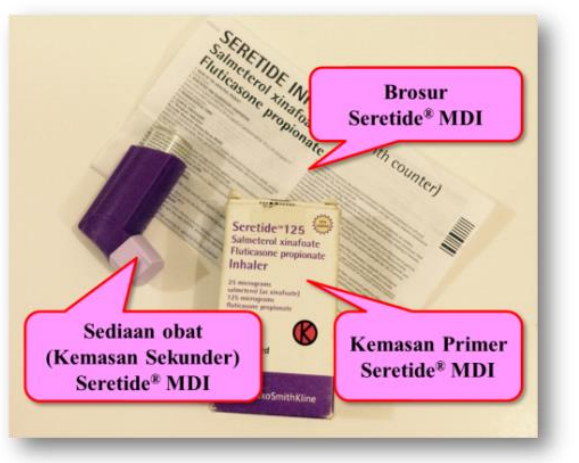

Gambar 1. Sediaan Seretide ${ }^{\circledR}$ MDI yang Terdiri dari: Kemasan Primer, Sediaan Obat, dan Brosur

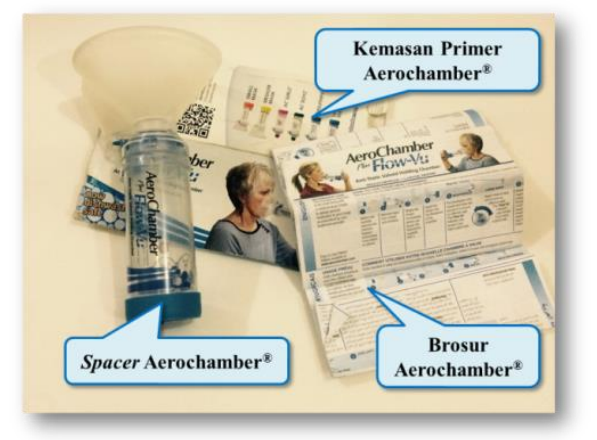

Gambar 2. Sediaan Alat Kesehatan Spacer Aerochamber $®$ dengan mask yang Terdiri dari: Kemasan Primer, Alat, dan Brosur

Peneliti dan rekan peneliti berperan sebagai interrater, dengan mengamati demonstrasi dari apoteker saat memperagakan sediaan Seretide ${ }^{\circledR}$ MDI dengan spacer (Aerochamber®). Peneliti juga dibekali alat perekam untuk merekam saat pembicaraan berlangsung. Sesaat setelah meninggalkan apotek, kedua interrater harus mengisi lembar checklist langkah penggunaan sediaan MDI dengan spacer, kemudian keduanya segera berdiskusi untuk menentukan kesepakatan hasil pengamatan dari persepsi kedua interrater (interrater reliability), dan dapat ditunjang dengan data rekaman saat pengambilan data.

d. Pengisian Checklist oleh interrater. Peneliti dan rekan peneliti (dua interrater) mengisi checklist sesuai pengamatan masingmasing, kemudian keduanya mencocokkan hasil pengamatan masing-masing tersebut. Apabila ada hasil pengisian checklist yang berbeda antar interrater maka kedua interrater menggunakan hasil rekaman sebagai data penunjang, dan apabila kedua interrater masih belum menemukan kesepakatan, maka dilakukan penilaian ulang terhadap apoteker tersebut dan apabila apoteker tidak bersedia maka data penelitan dari apoteker tersebut di dropout. Dalam pelaksanaan penelitian ini, peneliti merangkap sebagai interrater dan bersama seorang interrater lain yang telah menyamakan persepsi dahulu sebelum mulai penelitian.

\section{Metode Analisa Data \\ Metode Penilaian Kejelasan Penjelasan Setiap Step terkait Informasi Cara Penggunaan MDI dengan Spacer}

Menurut Kamus Besar Bahasa Indonesia (KBBI) online tahun 2014, istilah kata "menjelaskan" adalah sama dengan (1) menerangkan; membuat terang; menjadikan jelas; menguraikan supaya jelas; memberi penjelasan; (2) mengatakan; mengungkapkan; mengemukakan; (3) menyatakan dengan tegas; menegaskan; (4) menjadikan terang pada penglihatan (pendengaran dan sebagainya); (5) menunjukkan (menandakan) bahwa...

Berdasarkan definisi tersebut maka dalam memberikan informasi yang baik sebaiknya dilakukan melalui pendengaran dan penandaan (penglihatan), sehingga informasi penjelasan cara penggunaan MDI dengan spacer sebaiknya juga diberikan dengan cara diperagakan dan dijelaskan secara lisan. Data yang terkumpul kemudian diklasifikasikan menjadi tiga, yaitu: (A.) Apoteker memberikan informasi dengan cara diperagakan saja; (B.) Apoteker memberikan informasi dengan cara dijelaskan saja secara lisan; dan (C.) Apoteker memberikan informasi dengan cara diperagakan dan dijelaskan secara lisan.

Metode Penilaian Kelengkapan Penjelasan Setiap Step terkait Informasi Cara Penggunaan MDI dengan Spacer

Metode penilaian berdasarkan penjabaran dari tabel 1, setiap langkah diberi nilai 1 . Evaluasi data secara deskriptif berdasarkan 8 langkah (16 step) dari MDI dan spacer, dan tiap nomor mendapat nilai 1 tanpa melihat apakah apoteker memperagakan dengan memberikan informasi dengan cara 
diperagakan saja/ dijelaskan secara lisan/ keduanya.

\section{HASIL PENELITIAN \\ Distribusi Frekuensi Populasi dan Sampel Penelitian}

Berdasarkah hasil observasi terhadap semua apotek yang terdaftar di Wilayah Surabaya Timur berdasarkan data Dinas Kesehatan (2013) sebanyak 335 apotek, diketahui bahwa jumlah apoteker yang mewakili setiap apotek dalam populasi terjangkau adalah sebanyak 122 apoteker dan yang bersedia menjadi sampel penelitian adalah sebanyak 22 apoteker $(6,57 \%$ dari jumlah apoteker di Surabaya Timur).

Kelengkapan Informasi Penggunaan MDI dengan Spacer yang Diberikan Oleh Apoteker di Apotek di Surabaya Timur

Berdasarkan Tabel 2, menunjukkan bahwa step yang paling banyak dan lengkap adalah step 5a (tekan tabung canister MDI ke bawah untuk menyemprotkan satu semprotan), dan pada step ini semua apoteker mampu menjelaskan secara lisan dengan memperagakan langsung pada peneliti. Selain itu, pada step 6 (bernafaslah dengan menarik dan menghembuskan udara) juga semua sampel penelitan yang menjelaskan secara lengkap dengan secara lisan dan menggunakan alat peraga, yaitu sebanyak 20 apoteker $(90,90 \%)$.

Sebagian besar apoteker menjelaskan setiap step secara lisan disertai memperagakan menggunakan alat secara langsung, yaitu pada step:1a $(77,27 \%), 1 \mathrm{~b}(77,27 \%), 2(81,81 \%), 3$ $(31,81 \%), \quad 4 \mathrm{a}(59,09 \%), \quad 4 \mathrm{~b} \quad(13,63 \%), \quad 5 \mathrm{a}$ $(100 \%), \quad 5 b \quad(63,63 \%), \quad 6 a \quad(90,90 \%), 6 b$ $(40,90 \%)$, 8a $(9,09 \%)$, dan 8 b $(9,09 \%)$ (Tabel 2).

Step yang paling sedikit dijelaskan oleh apoteker (sampel penelitian) adalah pada step 8a (bilas mulut dengan air dan keluarkan air tersebut) dan $8 \mathrm{~b}$ (membilas mulut dapat mengurangi beberapa efek samping, seperti lapisan putih di lidah atau sakit tenggorokan), yaitu masing-masing hanya 3 orang dari sampel penelitian yang menjelaskan step tersebut, dan masing-masing hanya 2 orang (9\%) yang menjelaskan secara lisan disertai penggunaan alat peraga (Tabel 2).

Tabel 2. Distribusi Frekuensi Kejelasan Penjelasan Penggunaan Sediaan MDI dengan Spacer oleh Sampel Penelitian yang menjawab Masing-masingStep

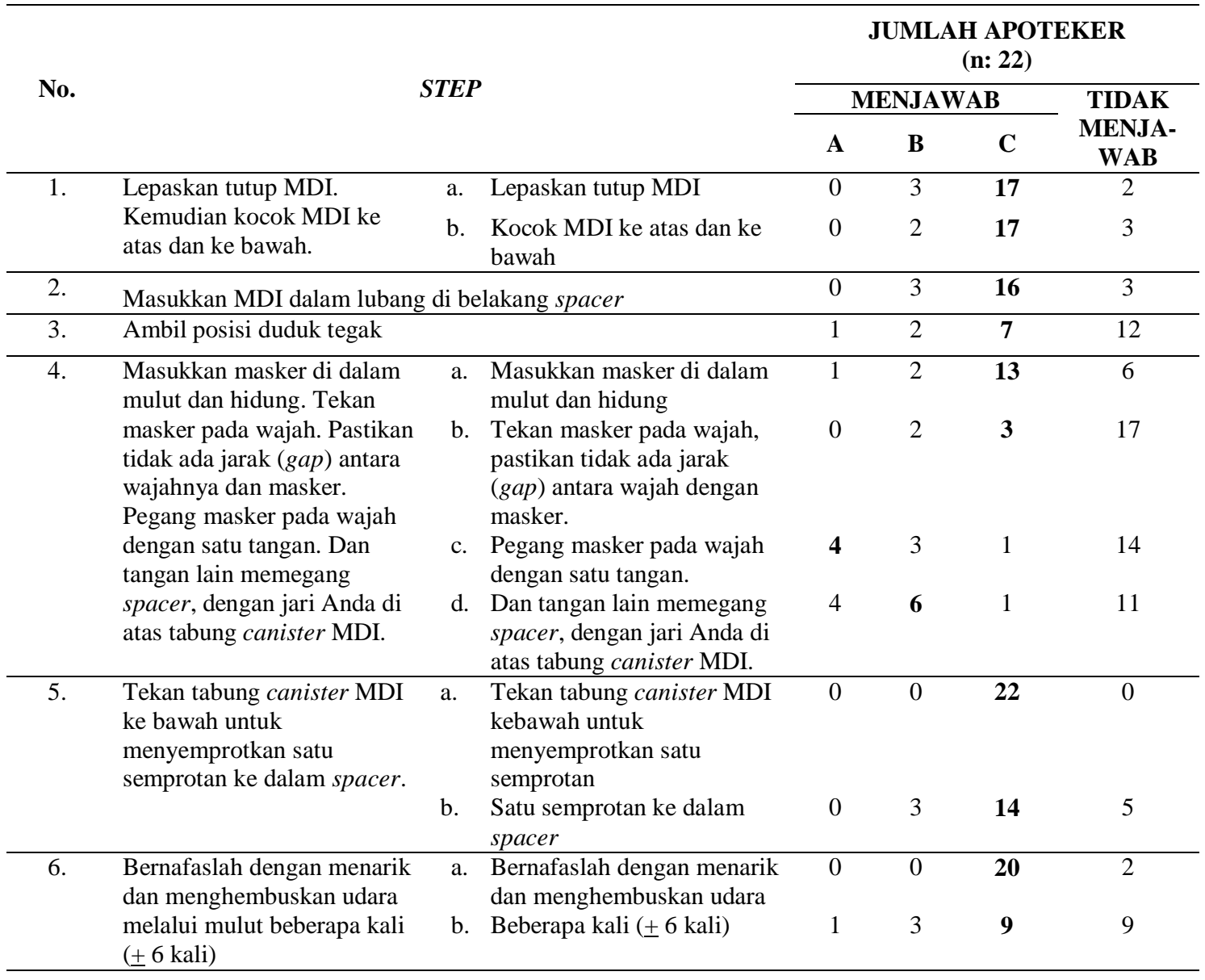




\begin{tabular}{|c|c|c|c|c|c|c|c|}
\hline \multirow{3}{*}{ No. } & & \multirow{3}{*}{\multicolumn{2}{|c|}{ STEP }} & \multicolumn{4}{|c|}{$\begin{array}{l}\text { JUMLAH APOTEKER } \\
\text { (n: 22) }\end{array}$} \\
\hline & & & & \multicolumn{3}{|c|}{ MENJAWAB } & \multirow{2}{*}{$\begin{array}{c}\text { TIDAK } \\
\text { MENJA- } \\
\text { WAB }\end{array}$} \\
\hline & & & & $\mathbf{A}$ & B & C & \\
\hline 7. & $\begin{array}{l}\text { Jika dibutuhkan lebih dari } \\
\text { satu semprotan obat, ulangi } \\
\text { langkah } 5-7 \text {. Jangan } \\
\text { menyemprotkan lebih dari } \\
\text { satu semprotan dalam satu } \\
\text { waktu ke dalam spacer. }\end{array}$ & $\begin{array}{l}\text { a. } \\
\text { b. }\end{array}$ & $\begin{array}{l}\text { Jika dibutuhkan lebih dari } \\
\text { satu semprotan obat, ulangi } \\
\text { langkah } 5-7 \\
\text { Jangan menyemprotkan } \\
\text { lebih dari satu semprotan } \\
\text { dalam satu waktu ke dalam } \\
\text { spacer. }\end{array}$ & 1 & 7 & 3 & 11 \\
\hline 8. & $\begin{array}{l}\text { Bilas mulut dengan air dan } \\
\text { keluarkan air tersebut } \\
\text { (jangan ditelan). Membilas } \\
\text { mulut dapat mengurangi } \\
\text { beberapa efek samping, } \\
\text { seperti lapisan putih di lidah } \\
\text { Anda (infeksi jamur yang } \\
\text { disebut thrust) atau sakit } \\
\text { tenggorokan. }\end{array}$ & & $\begin{array}{l}\text { Bilas mulut dengan air dan } \\
\text { keluarkan air tersebut. } \\
\text { Membilas mulut dapat } \\
\text { mengurangi beberapa efek } \\
\text { samping, seperti lapisan } \\
\text { putih di lidah atau sakit } \\
\text { tenggorokan }\end{array}$ & 0 & 1 & 2 & $\begin{array}{l}19 \\
19\end{array}$ \\
\hline
\end{tabular}

Keterangan:

A : apoteker memberikan informasi dengan cara diperagakan saja

B : apoteker memberikan informasi dengan cara dijelaskan saja secara lisan

C : apoteker memberikan informasi dengan cara diperagakan dan dijelaskan secara lisan

Tabel 3. Kelengkapan Penjelasan Penggunaan Sediaan MDI dengan Spacer oleh Sampel Penelitian yang menjawab Masing-masing Step

\begin{tabular}{|c|c|c|c|c|}
\hline \multirow{2}{*}{$\begin{array}{l}\text { KELENGKAPAN PENJELASAN } \\
\text { PENGGUNAAN SEDIAAN MDI DENGAN } \\
\text { SPACER OLEH SAMPEL PENELITIAN }\end{array}$} & \multicolumn{2}{|c|}{ JUMLAH $(\mathbf{A}+\mathrm{B}+\mathrm{C})$} & \multicolumn{2}{|c|}{ JUMLAH (C) } \\
\hline & n: & Persentase (\%) & n: & Persentase $(\%)$ \\
\hline Total score: 3 & 1 & 4,55 & 3 & 13,64 \\
\hline Total score: 4 & 0 & 0 & 1 & 4,55 \\
\hline Total score: 5 & 2 & 9,09 & 6 & 27,27 \\
\hline Total score: 6 & 1 & 4,55 & 2 & 9,09 \\
\hline Total score: 7 & 4 & 18,18 & 2 & 9,09 \\
\hline Total score: 8 & 1 & 4,55 & 2 & 9,09 \\
\hline Total score: 9 & 4 & 18,18 & 3 & 13,64 \\
\hline Total score: 10 & 1 & 4,55 & 0 & 0 \\
\hline Total score: 11 & 2 & 9,09 & 2 & 9,09 \\
\hline Total score: 13 & 1 & 4,55 & 0 & 0 \\
\hline Total score: 14 & 3 & 13,64 & 0 & 0 \\
\hline Total score: 16 & 2 & 9,09 & 1 & 4,55 \\
\hline TOTAL & 22 & 100 & 22 & 100 \\
\hline
\end{tabular}

Keterangan:

total score maksimum: 16

Jumlah $(\mathrm{A}+\mathrm{B}+\mathrm{C}) \quad$ : Jumlah sampel penelitian berdasarkan kelengkapan penjelasan informasi cara penggunaan MDI dengan spacer, meliputi penjelasan informasi yang hanya diperagakan saja, dijelaskan secara lisan saja, dan keduanya.

Jumlah (C) : : Jumlah sampel penelitian berdasarkan kelengkapan penjelasan informasi cara penggunaan MDI dengan spacer secara lisan dan menggunakan alat peraga 
Selain kejelasan penjelasan penggunaan sadiaan MDI dengan spacer oleh sampel penelitian (apoteker), pada penelitian ini juga melihat kelengkapan penjelasan tersebut. Setiap step diberi nilai score sebesar 1 poin. Total score maksimum adalah sebesar 16 poin, yang berarti apoteker mampu menyebutkan semua step secara lengkap.

Pada penilaian total score dari kelengkapan penjelasan cara penggunaan MDI dengan spacer, tanpa membedakan kejelasan informasi yang diberikan, diketahui bahwa nilai maksimum yang didapat adalah sebesar 16 poin, dan ada 2 apotek yang mendapatkan nilai tersebut (Tabel 3). Pada Tabel 3, jumlah sampel penelitian yang penilaian kelengkapan penjelasan tanpa memperhitungkan apakah apoteker menjelaskan secara lisan saja/ menggunakan peraga saja/ keduanya, dapat dilihat pada kolom "JUMLAH $(\mathrm{A}+\mathrm{B}+\mathrm{C})$ ". Dengan nilai terbanyak adalah pada total score sebesar 7 poin (4 apoteker) dan 9 poin (4 apoteker), dan rata-rata total score adalah sebesar 9,55 poin.

Dalam memberikan penjelasan Informasi yang baik adalah dengan menjelaskan secara lisan disertai dengan menggunakan alat peraga. Pada penilaian kelengkapan total score oleh sampel penelitianyang menjelaskan secara lisan dan menggunakan peraga, dapat dilihat pada Tabel 3, pada kolom "JUMLAH (C)".

Diketahui bahwa nilai maksimum yang didapat adalah sebesar 15 poin, dan hanya 1 apotek yang mendapatkan nilai tersebut. Dengan nilai terbanyak adalah pada total score sebesar 5 poin (6 apoteker), dan rata-rata total score adalah sebear 6,82 poin.

Cara Apoteker Mendapatkan Informasi Tambahan dalam Memberikan Informasi Penggunaan MDI dengan Spacer

Pada saat pengumpulan data, setiap sampel penelitian diberi sediaan MDI (Seretide ${ }^{\circledR}$ MDI) dan spacer (Aerochamber ${ }^{\circledR}$ dengan mask), yang diletakkan di dalam kemasan primer beserta brosur dari masingmasing produk.Namun sebagian besar sampel penelitian tidak melihat/mencari informasi tambahan sebelum atau saat memberikan penjelasan cara penggunaan MDI dengan spacer pada peneliti, yaitu sebanyak 15 apoteker $(68,18 \%)$. Hanya 4 orang apoteker yang membaca brosur dan ada 3 orang apoteker berdiskusi dengan rekan kerja di apotek. Dalam penelitian ini, tidak diketahui siapa rekan kerja yang diajak berdiskusi oleh apoteker.
Ketersediaan dan Pelayanan Sediaan MDI dengan Spacer

Pada saat menemui apoteker (sampel penelitian), peneliti juga melakukan wawancara untuk mengetahui ketersediaan obat sediaan MDI, seperti Seretide ${ }^{\circledR}$ MDI dan spacer, seperti Aerochamber ${ }^{\circledR}$. Sebagian besar apoteker tidak menjual inhaler MDI dan spacer (10 apoteker $(45,45 \%))$, apotek pernah menjual MDI namun tidak pernah menjual spacer $(10$ apoteker $(45,45 \%))$, apotek menjual MDI saat ini namun tidak pernah menjual spacer (1 apoteker $(4,55 \%)$ ), dan ada satu apotek yang menjual MDI pada saat penelitian dan pernah menjual spacer (1 apoteker (4,55\%)).

Intensitas Pelayanan bagi Apotek yang Menyediakan MDI dengan Spacer

Berdasarkan wawancara dengan sampel penelitian, diketahui bahwa hampir sebagian apoteker mengaku bahwa tidak pernah melayani pasien yang menggunakan MDI dengan spacer di apotek (10 apoteker $(45,45 \%))$ dan ada 10 apoteker yang pernah melayani MDI dengan spacer namun sudah lama sekali $(45,45 \%)$. Sedangkan hanya 2 apoteker yang mengatakan jarang (kurang dari sebulan sekali) melayani pelayanan MDI dengan spacer (2 apoteker $(9,09 \%)$ ).

Cara Apoteker Mendapatkan Informasi Lebih Lanjut mengenai MDI dengan Spacer

Sebagian besar apoteker yang menjadi sampel penelitian mengatakan bahwa apabila mereka membutuhkan informasi lebih lanjut mengenai sediaan MDI dan spacer maka mereka akan mencarinya melalui internet $(54,55 \%)$, internet dan bertanya pada distributor $(9,09 \%)$, dan internet dan bertanya pada rekan kerja $(22,73 \%)$. Sedangkan sebagian kecil lainnya bertanya kepada distributor $(9,09 \%)$ dan rekan kerja $(4,55 \%)$.

\section{PEMBAHASAN \\ Keterlibatan Apoteker dalam Penelitian}

Apoteker sebagai bertanggung jawab dalam kegiatan kefarmasian di apotek, sehingga kehadiran apoteker di apotek telah menjadi hal wajib. Kehadiran apoteker berdasarkan PP No. 51 tahun $2009^{(18)}$, adalah apoteker hadir setiap dilakukan kegiatan kefarmasian, sehingga dapat diasumsikan kehadiran apoteker di apotek adalah setiap hari. Berdasarkan penelitian yang dilakukan oleh Kwando pada tahun 2013, menunjukkan bahwa pelaksanaan pelayanan kefarmasian oleh apoteker di apotek di Wilayah Surabaya Timur dikategorikan kurang dengan hasil persentase sebesar $<60 \%$, dan adanya korelasi signifikan positif antara frekuensi kehadiran apoteker dan pelayanan kefarmasian dan 
rendahnya upah/gaji apoteker yang merupakan kendala kehadiran apoteker di apotek ${ }^{\text {(21) }}$.

Pada penelitian ini, penilaian kehadiran apoteker berdasarkan hasil wawancara dengan apoteker di apotek tersebut. Sedangkan bagi apoteker yang menolak tanpa memberikan alasan yang jelas, maka kehadiran apoteker. Beberapa ulasan alasan ketidakbersediaan apoteker untuk menjadi sampel penelitian:

1. Tidak menjual inhaler (6 apoteker). Menurut Permenkes No. 35 tahun 2014 tentang Standar Pelayanan Kefarmasian di Apotek (12), tercantum bahwa apoteker harus memberikan konseling dan informasi obat, salah satunya kepada pasien dengan penyakit kronis (PPOK) dan pasien yang menggunakan obat dengan instruksi khusus atau alat khusus (inhaler). Di Permenkes tersebut tidak mensyaratkan KIE bagi apoteker terkait ketersediaan obat atau tidak, sehingga pelayanan KIE bagi penggunaan inhaler sudah menjadi kewajiban apoteker.

2. Pernah mengikuti penelitian lain (2 apoteker). Ada 2 apoteker yang menolak terlibat dalam penelitian karena baru beberapa bulan yang lalu mengisi kuesioner penelitian lain yang sejenis. Peneliti telah menjelaskan bahwa penelitian yang dilakukan ini memiliki tujuan yang berbeda dengan penelitian lain, namun apoteker menolak.

3. Mengaku sibuk (32 apoteker). Pada apoteker/tenaga kefarmasian lain yang mengatakan bahwa mereka sedang sibuk, peneliti telah menawarkan untuk membuat janji di waktu lain, namun ditolak.

4. Merasa di-test (7 apoteker). Beberapa peneliti yang merasa di-test meminta peneliti untuk mengisi checklist sesuai keinginan mereka. Akhirnya penilaian tidak dilanjutkan.

5. Menolak tanpa alasan (51 apoteker). Beberapa apoteker menolak tanpa memberikan alasan yang jelas .Ada beberapa penolakan yang dilakukan oleh tenaga kefarmasian lain tanpa bertanya/konfirmasi dengan apoteker, sehingga peneliti tidak mengetahui alasan apoteker menolak. Pada poin ini peneliti kesulitan menentukan apakah sampel memenuhi kriteria untuk menjadi populasi terjangkau ataukah tidak.

Pada penelitian ini lebih menggunakan interrater aggrement dibandingkan interrater reliability. Intterater aggrement adalah tingkat dimana dua ataau lebih evaluator memberikan nilai yang sama untuk mengidentifikaasi situasi secara observasional, sehingga hasil yang dapat digunakan adalah apabila kedua interrrater memberikan nilai yang sama ${ }^{(22)}$.
Pengukuran dengan interrater aggrement dengan skala nominal atau ordinal. Penggukuran dilakukan dengan metode Kappa, yaitu nilai $\mathrm{k}=1$ bila ada kesepakatan sempurna (semua interrater setuju), dan nilai $\mathrm{k}=0$ atau negatif bila tidak ada kesepakatan ${ }^{(23)}$. Pada penelitian ini tidak dilakukan perhitungan nilai Kappa, karena selama pengumpulan data, interrater dalam penelitian ini tidak menemukan perbedaan pendapat yang berarti, sehingga tidak pernah meminta sampel penelitian untuk mengulang penjelasan kembali.

Pembahasan Kelengkapan Tiap Langkah dari Informasi Penggunaan MDI dengan Spacer yang Diberikan oleh Apoteker Pembahasan Step 1: Lepaskan Tutup MDI, Kemudian Kocok MDI Keatas dan Kebawah.

Pada step ini, interrter tidak mengalami kesulitan dalam menilai, karena penilaian relatif mudah dan dapat diamati dengan jelas. Pada step ini apabila tidak dilakukan maka tidak dapat dipakai secara cepat karena dosis pada saat terjadi eksaserbasi asma tidak dapat keluar dari mouthpiece MDI, membuka tutup inhaler bertujuan untuk membuka jalan obat melalui alat inhalasi ${ }^{(9,14)}$. Mouthpiece pada MDI merupakan area pengarah aliran droplet aerosol yang keluar dari atomizing nozzle menuju rongga mulut untuk pada akhirnya di alirkan ke paru-paru ${ }^{(9)}$. Penutup (cap) MDI bertujuan untuk melindungi mouthpiece dimana partikel yang disemprotkan akan keluar melalui mouthpiece yang merupakan tempat keluarnya droplet aerosol yang keluar dari atomizing nozzle menuju rongga mulut kemudian dilanjutkan ke paru-paru. Atomizing nozzle merupakan pipa semprot tempat keluarnya droplet aerosol dari tabung canister $^{(9)}$. Pada saat pengambilan data penelitian, apoteker yang memperagakan cara penggunaan MDI dengan spacer, sering tidak menjelaskan secara detail bagaimana cara mengocok MDI dan hanya mengatakan bahwa "MDI harus dikocok terlebih dahulu". Pengocokan metered-dose inhaler (MDI) berfungsi untuk menghomogenkan formula suspensi dan menyeragamkan dosis karena masalah utama yang sering kali terjadi pada pasien yang menggunakan metered-dose inhaler (MDI) adalah tidak mengocok tabung atau canister inhaler sebelum digunakan ${ }_{(\mathbf{9}, \mathbf{1 0})}$ dan dipertahankan dalam posisi tegak ${ }^{(9)}$. Kesalahan umum yang muncul terkait penggunaan MDI adalah pasien tidak mengocok MDI sebelum digunakan sehingga patikel yang disemprotkan tidak seragam, mengakibatkan pengurangan dosis sebanyak $33 \%$ dari jumlah dosis yang seharusnya tersampaikan $^{(10)}$. Selain itu, banyak ukuran 
partikel tidak seragam dapat berakibat partikel besar akan menempel atau terdeposit pada bagian langit-langit mulut atau bagian dalam mulut yang kemungkinan terjadi efek samping candidiacis oropharyngeal $^{(8)}$.

\section{Pembahasan Step 2: Masukkan MDI dalam} lubang di belakang Spacer.

Sebagian besar apoteker mengatakan tidak pernah melihat alat spacer dan semua apoteker tidak mengaku tidak pernah menjual di masing-masing apoteknya. Sehingga nampak bahwa apoteker juga baru pertama kali menjelaskan cara penggunaan spacer pada pemakaian MDI. Sebagian besar apoteker mengetahui step ini karena kemasan sekunder spacer yang sudah menampilkan gambar spacer yang terpasang dengan MDI, sehingga apoteker dapat menjelaskan tanpa melihat brosur. Namun, pada pengamatannya, interrater agak kesulitan membedakan antara apoteker yang memang memahami cara penggunaan alat spacer dengan apoteker yang dapat menjelaskan step ini karena mencobacoba saat membuka alat dari kemasan primernya. Semua apoteker yang menjelaskan step ini, memperagakan pemasangan MDI ke dalam spacer dengan posisi yang benar yaitu posisi MDI dalam keadaan tegak. Apabila kondisi metered-dose inhaler (MDI) terbalik dengan mouthpiece pada posisi di atas maka ada kemungkinan pasien mengalami kesulitan dalam melakukan aktuasi tabung canister. Selain itu, akan berdampak pada menurunnya efektivitas obat yang berkaitan dengan gaya gravitasi dimana akan mempengaruhi distribusi ukuran partikel obat aerosol yang umumnya memiliki ukuran partikel kisaran 1$5 \mu \mathrm{m}^{(24)}$.

\section{Pembahasan Step 3: Ambil posisi duduk tegak.}

Sebagian besar apotek tempat apoteker (sampel penelitian) bekerja tidak memiliki ruang konseling khusus, sehingga proses wawancara dilakukan dalam posisi berdiri (20 apotek). Oleh karena itu, interrater agak susah membedakan antara apoteker yang memang memberikan konseling dalam posisi berdiri atau apoteker yang menjelaskan bahwa penggunaan MDI dengan spacer harus dalam posisi tegak, sehingga dalam menentukan penilaian, interrater sepakat istilah posisi tegak harus tegak lurus dengan sempurna. Duduk/ berdiri dan tahan kepala tegak, dengan memegang MDI dengan posisi mulut inhaler berada di bagian bawah ${ }^{(14)}$. Step ini bertujuan agar mempermudah pasien menerima dosis yang tepat. Disarankan pada saat melakukan inhalasi, dilakukan dalam posisi berdiri atau duduk tetapi tidak disarankan sambil berbaring. Mulut inhaler atau mouthpiece MDI berada dibawah pada posisi bawah bertujuan agar mempermudah pasien saat melakukan aktuasi tabung metered-dose inhaler (MDI) ${ }^{(9)}$.

Pembahasan Step 4: Masukkan masker di dalam mulut dan hidung. Tekan masker pada wajah. Pastikan tidak ada jarak (gap) antara wajahnya dan masker. Pegang masker pada wajah dengan satu tangan. Dan tangan lain memegang spacer, dengan jari Anda di atas tabung canister MDI.

Penilaian poin pada step ini terkait dengan cara memposisikan spacer dan MDI. Dalam pelaksanaannya, apoteker tidak semuanya meletakkan masker di mulut secara menempel, kemungkinan disebabkan apoteker berbicara sambil menjelaskan, atau ada kemungkinan apoteker enggan meletakkan masker menempel ke mulut dikarenakan higienitas. Ada pula seorang apoteker yang menjelaskan dengan mengatakan dan memperagakan namun meletakkan masker secara terbalik, sehingga interrater sepakat ditak memberikan nilai. Selain dalam bentuk mouthpiece, spacer juga terkadang dilengkapi dengan mask yang biasanya lebih mudah digunakan dan sering direkomendasikan bagi usia anak-anak (19) Pada penelitian ini, jenis spacer yang digunakan adalah spacer dengan mask. Penggunaan spacer juga membantu bagi pasien yang kesulitan dalam koordinasi MDI, seperti pada pengunaan MDI yang perlu meletakkan mouthpiece pada bagian antara gigi dan tutup bibir dengan rapat (kondisi mulut tertutup rapat) ${ }^{(14)}$, supaya aliran udara tidak terganggu dengan jalan lidah yang menutupi bagian mouthpiece $\mathrm{MDI}^{(9)}$.

Pembahasan Step 5: Tekan tabung canister MDI kebawah untuk menyemprotkan satu semprotan ke dalam spacer.

Pada saat pengumpulan data, sebagaian besar apoteker hanya memperagakan dengan memberi petunjuk untuk menekan tabung canister MDI (sambil menunjuk tabung) namun tidak menekan tabung canister tersebut. Kemungkinan hal ini disebabkan apoteker menduga bahwa dalam prakteknya pemberian KIE, apabila obat benar-benar disemprotkan maka akan mengurangi jumlah obat yang akan digunakan oleh pasien. Oleh karena itu, intterater sepakat untuk tetap memberikan penilaian kepada apoteker yang telah memperagakan/ mengilustrasikan saja namun tidak menekan canister, tetapi dengan syarat apoteker telah memberikan petunjuk untuk menekan sebanyak satu kali pada bagian canister tabung. Pentingnya step ini bagi pasien supaya dapat menerima dosis dengan tepat dan untuk mengkondisikan posisi obat berada lebih tinggi dari jalan keluarnya obat ${ }^{(9)}$. Apabila posisi canister kebalik maka yang 
akan terjadi yaitu dapat mengurangi efektifitas obat yang berkaitan dengan gaya gravitasi yang pada dasarnya gaya aerodinamika berpengaruh pada distribusi ukuran partikel optimum untuk sebagian besar aerosol inhalasi secara umum telah diakui sebagai berada di kisaran 1-5 $\mu \mathrm{m}^{(24)}$. Ada beberapa apoteker yang memperagakan yang menjelaskan dengan memperagakan cara penyemprotan ke dalam spacer, namun mereka memperagakan dengan menyemprotkan beberapa kali (lebih dari satu semprotan) ke dalam spacer (2 apoteker), maka pada poin step ini tidak mendapatkan nilai. Karena penggunaan spacer yang benar adalah satu kali semprot setiap kali dihirup, dan apabila butuh bebrapa kali semprotan, dapat diulang. Apabila tidak menunggu setelah setiap semprotan, obat dapat menyebabkan sedikit atau tidak ada obat yang disampaikan selama aktuasi berikutnya karena ruang metering mungkin tidak diisi ulang sepenuhnya dan redistribusi obat dan propelan gas akan inadekuat ${ }^{(9)}$.

\section{Pembahasan Step 6: Bernafaslah dengan menarik dan menghembuskan udara melalui mulut beberapa kali $( \pm 6$ kali).}

Sebagian besar apoteker yang menjelaskan step 6 ini memperagakan menarik nafas dan mengehembuskan nafas, tidak menjelaskan kapan mulai bernafas (inspirasi) dari saat obat MDI ditekan. Inspirasi harus dimulai selambat-lambatnya 1-3 detik setelah MDI ditekan, karena setelah obat adalah disemprotkan maka obat akan tersuspensi dalam chamber kurang dari 10 detik $^{(9)}$.

Pada step ini bertujuan untuk memberikan waktu bagi paru-paru agar dapat kontak dengan obat. Pada step ini, pasien harus menarik napas perlahan dan dalam melalui mulut dengan inhalasi penuh selama 35 detik untuk membuka katup, yang memungkinkan obat untuk meninggalkan spacer. Jika pasien bernapas terlalu cepat, obat akan memukul bagian belakang tenggorokan dan mulut ${ }^{(9)}$. Hal ini adalah salah satu keuntungan penggunaan MDI dengan spacer dibandingkan dengan MDI tanpa spacer, dimana pada penggunaan MDI tanpa spacer, pasien harus menahan nafas selama 10 detik agar partikel obat dapat terdeposisi secara maksimal dan optimal di paru-paru serta menahan nafas dapat memberikan waktu pengobatan menetap atau bertahan lama pada saluran pernafasan ${ }^{(\vartheta, 14)}$, Menahan nafas selama waktu 10 detik merupakan waktu yang efektif untuk partikel obat terdeposisi pada paru-paru apabila pasien asma tidak dapat menahan nafas selama 10 detik maka diperbolehkan menahan kurang dari 10 detik (misal selama 5 detik atau 7 detik) selama pasien mampu melalukannya, waktu minimal untuk menahan nafas yaitu 4 detik. Pasien asma yang melalukan step ini bila menahan nafas lebih dari 10 detik tidak akan menimbulkan optimal yield value atau tidak menimbulkan efektifitas obat berlebih ${ }^{(9)}$. Pada pasien yang tidak dapat menahan nafas cukup lama, maka dapat menggunakan spacer untuk penggunaan MDI-nya.

Pembahasan Step 7: Jika dibutuhkan lebih dari satu semprotan obat, ulangi langkah 57 dan Jangan menyemprotkan lebih dari satu semprotan dalam satu waktu ke dalam spacer.

Pada step 7 ini, penjelasan sering bersamaan saat penjelaan step 5 , terkait jumlah semprotan obat MDI kedalam spacer. Interrater tidak mempermasalahkan urutan pada saat menyebutkan satu kali penyemprotan setiap kali digunakan (step 7b), asalkan tidak mengubah pengertian dalam checklist. Step ini perlu dijelaskan bagi pasien yang menggunakan obat beberapa semprotan. Ada beberapa apoteker yang memperagakan yang menjelaskan dengan memperagakan cara penyemprotan ke dalam spacer, namun mereka memperagakan dengan menyemprotkan beberapa kali (lebih dari satu semprotan) ke dalam spacer (2 apoteker), maka pada poin step ini tidak mendapatkan nilai. Karena penggunaan spacer yang benar adalah satu kali semprot setiap kali dihirup, dan apabila butuh bebrapa kali semprotan, dapat diulang. Apabila tidak menunggu setelah setiap semprotan, obat dapat menyebabkan sedikit atau tidak ada obat yang disampaikan selama aktuasi berikutnya karena ruang metering mungkin tidak diisi ulang sepenuhnya dan redistribusi obat dan propelan gas akan inadekuat. Jika dibutuhkan lebih dari satu dosis, tunggu 30 detik sampai 1 menit antar puff dan ulangi semua langkah lagi dari awal. Jika tidak menunggu cukup lama, puff berikutnya tidak akan memberikan dosis yang benar. Kocok puffer (ulangi langkah 2-8). Ganti tutup pada MDI untuk membantu tetap bersih. Beberapa pasien mencoba untuk menghemat waktu dengan menyemprotkan lebih dari satu dosis ke dalam ruang memegang pada satu waktu, tetapi ini akan mengurangi jumlah obat yang akan mencapai paru-paru ${ }^{(9)}$.

Pembahasan Step 8: Bilas mulut dengan air dan keluarkan air tersebut (jangan ditelan). Membilas mulut dapat mengurangi beberapa efek samping, seperti lapisan putih di lidah Anda ( infeksi jamur yang disebut thrust) atau sakit tenggorokan.

Pada step 8, apoteker harus menjelaskan bahwa setelah menggunaan obat, maka harus segera dibilas dengan air dan ait tidak boleh ditelan. Membilas mulut dapat mengurangi 
beberapa efek samping, seperti lapisan putih di lidah Anda (infeksi jamur yang disebut thrush) atau sakit tenggorokan ${ }^{(19)}$.

\section{Pembahasan informasi tambahan}

Sebagian besar apoteker tidak menggunakan informasi tambahan. Hali ini kemungkinan disebabkan brosur yang tersedia menggunakan bahasa inggris dan pada brosur Seretide ${ }^{\circledR}$ MDI tidak menyertakan gambar petunjuk, berbeda dengan spacer, dimana pada Aerochamber® menyertakan gambar petunjuk, seperti pada beberapa apoteker yang melihat sekilas, kemudian menutup kembali brosur obatnya, dan memberikan penjelasan tanpa menggunakan brosur. Informasi tambahan yang digunakan di penelitian ini adalah brosur yang terdapat pada sediaan controller MDI tersedia (Seretide ${ }^{\circledR}$ MDI) tidak tertera gambar demostrasi alat yang dapat memudahkan pasien asma menggunakan sediaan controller MDI. Selain brosur, beberapa apoteker bertanya pada rekan kerjanya, yang sebagian besara adalah assisten apoteker (ada pula yang bertanya pada sesama apoteker di tempat kerjanya). Sebagian besar apoteker yang bertanya pada assisten apoteker, mendapatkan jawaban yang kurang tepat sehingga poin penilaian tidak ada.

Sebagian besar apotek tidak menyediakan MDI (hanya ada 2 apotek), dan semua apotek tidak menyediakan spacer. Dalam wawancara peneliti bertanya kepada apoteker mengenai bagaimana mencari informasi lebih lanjut mengenai cara penggunaan MDI dengan spacer, dan sebagian besar menjawab intenet. Apoteker yang menjawab internet, memilih mencari melalui video cara penggunaan MDI dengan spacer dari youtube, karena dirasa lebih mudah dimengerti.

\section{Pembahasan keterbatasan penelitian}

Keterbatasan dalam penelitian ini antara lain:

a. Besar sampel penelitian yang lebih kecil dari besar sampel minimum. Hal ini dikarenakan apoteker di apotek banyak yang tidak bersedia menjadi sampel penelitian, sehingga dengan besar sampel yang kecil menyebabkan hasil penelitian kurang mewakili populasi. Hasil penelitian mewakili populasi terjangkau namun belum dapat digeneralisasi, karena semakin besar jumlah sampel maka semakin besar tingkat kepercayaan penelitian tersebut untuk digeneralisasikan.

b. Beberapa apoteker merasa tidak nyaman melakukan wawancara dengan alat perekam suara, sehingga ada beberapa wawancara yang dilakukan tanpa alat perekam suara. Padahal alat perekam suara ini dapat membantu interrater bila mengalami perbedaan pendapat dalam pengisian data.
Idealnya, wawancara sebaiknya didokumentasikan dengan video, sehingga tidak hanya mendokumentasikan suara, tapi juga gerakan yang menggambarkan peragaan oleh apoteker pada saat menjelaskan cara penggunaan MDI dengan spacer.

c. Ketersediaan apoteker menjadi sampel penelitian relatif kecil. Berdasarkan hasil penelitian ini, maka daat disarankan untuk penelitian selanjutnya dapat bekerjasama dengan isntansi yang lebih besar (contoh: IAI/ Ikatan Apoteker Indonesia) agar dapat meningkatkan kesediaan sampel penelitian. Seperti melalui workshop mengenai cara pengobatan sediaan inhaler pada asma di komunitas, dimana dapat mengumpulkan banyak apoteker. Dan dalam workshop tersebut dapat dilakukan penilaian sebelum pelatihan untuk mengetahui profil apoteker dalam memberikan penjelasan mengenai cara penggunaan inhaler.

d. Hasil Penilaian dari penelitian ini hanya menggambarkan kelengkapan dari informasi yang diberikan apoteker dalam menjelaskan teknik penggunaan MDI dan spacer, dan hasil penelitian belum melingkupi semua komponen KIE secara menyeluruh pada obat yang menggunakan inhaler untuk pengobatan PPOK. Sesuai dengan Permenkes Nomor 35 Tahun 2014 ${ }^{(12)}$, informasi obat dapat meliputi dosis, bentuk sediaan, formulasi khusus, rute dan metoda pemberian, farmakokinetik, farmakologi, terapeutik dan alternatif, efikasi, keamanan penggunaan pada ibu hamil dan menyusui, efek samping, interaksi, stabilitas, ketersediaan, harga, sifat fisika atau kimia dari obat dan lain-lain. Namun pada penelitian ini, baru meneliti mengenai metode pemberian saja.

\section{SIMPULAN}

Dari hasil penelitian, maka dapat disimpulkan bahwa berdasarkan kejelasan informasi cara penggunaan MDI (metereddose inhaler) dengan spacer, menunjukkan bahwa sebagian besar apoteker menjelaskan secara lisan disertai peragaan dengan alat peraga. Sedangkan berdararkan informasi yang dinilai dari total score dari step yang dijelaskan oleh apoteker, menunjukkan hanya ada satu apoteker yang dapat menjelaskan semua step secara lengkap dan penjelasan dilakukan secara lisan dengan disertai peragaan dengan alat peraga.

\section{UCAPAN TERIMA KASIH}

Peneliti mengucapkan terima kasih kepada Lembaga Penelitian dan Pengabdian kepada Masyarakat Universitas Surabaya (UBAYA) atas dukungan materiil dalam pelaksanaan penelitian ini. Penelitian ini dibiayai oleh Lembaga Penelitian dan Pengabdian Masyarakat (LPPM) Universitas Surabaya. 


\section{DAFTAR PUSTAKA}

1. Williams, D. M., \& Bourdet, S. V. (2008). Chronic obstructive pulmonary disease. In J. T. Dipiro, R. L. Talbert, G. C. Yee, G. R. Matzke, B. G. Wells, \& L. M. Posey (Eds.), Pharmacotherapy: a pathophysiologic approach (7 ed.), pp. 495-517). New York, NY: McGraw Hill.

2. Oemiati, 2013, Kajian Epidemiologis Penyakit Paru Obstruktif Kronik (PPOK). Media Litbangkes. 23(2): 82-88.

3. Global Obstructive Lung Disease (GOLD), 2017, Global Initative for Chronic Obstructive Lung Disease (Update).

4. American Thoracic Society (ATS) / European Respiratory Society Task Force. Standards for the Diagnosis and Management of Patients with COPD [Internet]. Version 1.2. New York: American Thoracic Society; 2004 「13 September 2014]. Available from: http://www.thoracic.org/go/copd.

5. Odili VU dan Okoribe CO, 2010, Assessment of Pharmacists' knowledge on correct inhaler technique. Research Journal of Pharmaceutical, Biological and Chemical Sciences. 1(3):768-772.

6. National Asthma Council Australia, 2008, Inhaler technique in adultswith asthma or COPD (online). (www.nationalasthma.org.au)

7. National Institute for Health and Care Excellence (NICE), 2010, Chronic obstructive pulmonary disease: Management of chronic obstructive pulmonary disease in adults in primary and secondary care.

8. Global Initiative for Asthma, 2017, Global Strategy for Asthma Management \& Prevention (Update).

9. Beaucage D dan Nesbittt S, 2002, Using Inhalation Device, in Bourbeau, Nault, Borycki, Comprehensive Management of Chronic Obstructive Pulmonary Disease, BC Decker Inc., Canada, p.83-107.

10. NACA (National Asthma Council Australia), 2008, Inhaler Technique in Adults with Asthma or COPD

11. Onda M, Sakurai H, Hayase Y, Sakamaki H, Arakawa Y, Yasukawa F, 2009, Effects of Patient-Pharmacist Communication on the Treatment of Asthma, Yakugaku Zasshi, 129(4):427-433.

12. Peraturan Menteri Kesehatan RI Nomor 35 tahun 2014 tentang Standar Pelayanan Kefarmasian di Apotek.

13. Baddar SA, Al-Rawas OA, Al-Riyami KA, Worthing EA, Hanssens YI, Taqi AM, AlRiyami BMS, 2001, Metered-dose inhaler technique among healthcare providers practising in Oman. squ journal for scientific research: Medical Sciences 2001, 1, 39-43.

14. Osman A, Hassan ISA, Ibrahim MIM, 2012, Are Sudanese community pharmacists capableto prescribe and demonstrate asthma inhaler devices to patrons? A mystery patient study. Pharmacy Practice (Internet) 2012 Apr-Jun;10(2):110-115.

15. Lorensia A, Queljoe DD, Santoso ZD, Setiawan H. 2015 a Completeness of Information of Metered-dose Inhaler (MDI) Use in Asthma Patients in Pharmacies [Oral Presentation]. The 4th International Conference on Pharmacy and Advanced Pharmaceutical Sciences: Integrating Sosioenterpreneurship in Marine Development for Sustainable Pharmacy. Organized by Gadjah Mada University, Indonesia, in cooperation with Universiti Sains Malaysia, Malaysia, and Nara Institute of Science and Technology (NAIST) Jepang. In Sheraton Mustika Hotel Resort dan Spa Yogyakarta, Yogyakarta. 7-8 September 2015.

16. Lorensia A, Queljoe DD, Santosa KA. $2015^{\mathrm{b}}$. Kelengkapan Informasi Mengenai Cara Penggunaan Peak Flow Meter yang Diberikan kepada Pasien Asma di Apotek. Jurnal Ilmiah Manuntung (JIM) Sains Farmasi dan Kesehatan, Akademi Farmasi Samarinda, December 2015, Vol. 1, No. 2, p8-18.

17. Lorensia A, Queljoe DD, Karina BL, Hewu A. 2016. Studi Kelengkapan Penjelasan Cara Penggunaan Sediaan Controller Inhaler (Kombinasi Kortikosteroid Dengan Beta-2 Agonis) Jenis Diskus ${ }^{\circledR}$ Dan Turbuhaler ${ }^{\circledR}$ Oleh Apoteker Di Apotek. Jurnal Ilmiah Manuntung (JIM) Sains Farmasi dan Kesehatan, Akademi Farmasi Samarinda. Desember 2016; 2(2):137-146).

18. Peraturan Pemerintah nomer 51 tahun 2009 tentang Pekerjaan Kefarmasian.

19. Canadian Lung Association, 2013, How to Use a Puffer with a Spacer (also Called a Valved Holding Chamber). http://www.lung.ca/diseases-maladies/helpaide/devices-dispositifs/pufferpompe_e.php\#mask

20. Sari, I.P., 2004, Penelitian Famasi Komunitas dan klinik. Gadjah Mada University Press. p.31.

21. Kwando RR, 2014, Pemetaan Peran Apoteker dalam Pelayanan Kefarmasian Terkait Frekuensi Kehadiran Apoteker di Apotek di Surabaya Timur. Jurnal Ilmiah Mahasiswa Universitas Surabaya; 3(1):1-12.

22. Graham M, Milanowski A, Miller J, Westat. 2012. Measuring and Promoting Inter-Rater Agreement of Teacher and Principal Performance Ratings. The Center for Educator Compensation and Reform (CECR). (online).

23. MedCalc, 2014. Interrater Aggrement (Kappa). (online) (http://www.medcalc.org/manual/kappa.php)

24. Food and Drug Administration Center for CDER, 1998, Guide for Industry: Metereddose Inhaler (MDI) and Dry Powder Inhaler (DPI) Drug Products. Nov 13 


\section{JURNAL ILMIAH MANUNTUNG}

Announcements About Current Archives Focus and Scope Publication Ethics

\section{Search}

Home / Editorial Team

\section{Director}

- Supomo, M.Si., Apt., Akademi Farmasi Samarinda, Indonesia

\section{Chief Editor}

- Yulia Sukawaty, M.Sc., Apt., Akademi Farmasi Samarinda, Indonesia

\section{Editors}

- Reksi Sundu, M.Sc., Apt., Akademi Farmasi Samarinda, Indonesia

- Henny Nurhasnawati, S.Si., M.Si., Akademi Farmasi Samarinda, Indonesia

- Risa Supriningrum, S.Si., M.M., Akademi Farmasi Samarinda, Indonesia

- Eka Siswanto, M.Sc., Apt., Akademi Farmasi Samarinda, Indonesia

- Hayatus Sa'adah, M.Sc., Apt., Akademi Farmasi Samarinda, Indonesia

- Husnul Warnida, M.Si., Apt., Akademi Farmasi Samarinda, Indonesia

\section{Reviewer}

- Prof. Enos Tangke Arung, PhD, Fakultas Kehutanan, Universitas Mulawarman, Samarinda, Indonesia

- Prof. Dr. Nurfina Aznam, SU., Apt, Universitas Negeri Yogyakarta, Indonesia

- Prof. Dr. Jansen Silalahi, M.App.Sc., Apt, Universitas Sumatera Utara, Indonesia 
- Irawan Wijaya Kusuma, PhD, Universitas Mulawarman, Indonesia

\section{Administration}

- Irwansyah, Akademi Farmasi Samarinda, Indonesia

\section{Akreditasi}

\section{Policies}

Author Charge

\section{Editorial Team}

Plagiarism Policy

Open Acces Policy

Digital Archiving

Copyright Notice 
Template_Journal

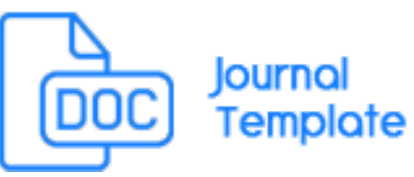

\section{VISITORS}

\section{Visitors

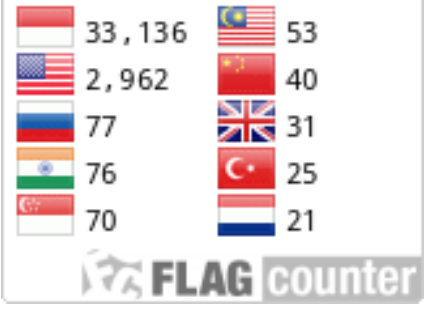

00067730 View My Stats

\section{INDEXED}

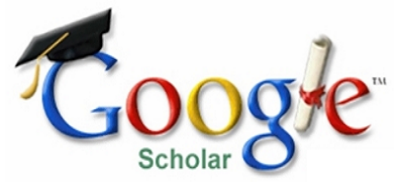

1 indonesta Onesearch<smiles>[GeH3]</smiles>
PKP INDEX BASE 


\section{A GARUDA}

\section{LPPM Akademi Farmasi Samarinda}

Jl. Brig. Jend. Abdul Wahab Sjahranie No. 226, Air Hitam

Samarinda, Kalimantan Timur, Indonesia

Telp : (0541) 7777363

Email : ejournal.akfarsam@gmail.com

\section{(c) (i) (-)}

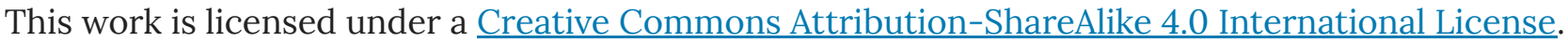

$$
\begin{aligned}
& \text { powered by OJS | Open Journal systems } \\
& \text { PKP | PUBLIC KNOWLEDGE PROJECT }
\end{aligned}
$$




\section{JURNAL ILMIAH MANUNTUNG}

Announcements About Current Archives Focus and Scope Publication Ethics

Sitemap

\section{Search}

Home / Archives / Vol 4 No 1(2018): Jurnal Ilmiah Manuntung

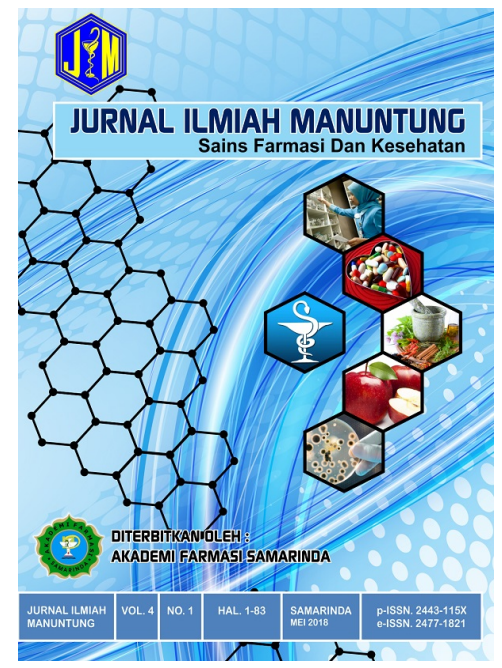

Jurnal Ilmiah Manuntung adalah Jurnal tentang Sains Farmasi dan Kesehatan yang diterbitkan oleh Akademi Farmasi Samarinda yang meliputi kajian Ilmu Farmasi, Kedokteran, Kimia Organik Sintetis, Kimia Organik Bahan Alam, Biokimia, Kimia Analisis, Kimia Fisis, Biologi, Mikrobiologi, Kultur Jaringan, Botani dan hewan yang terkait dengan produk farmasi, keperawatan, Kebidanan, Analis Kesehatan, Gizi dan Kesehatan Masyarakat.

Published: 2018-05-26

\section{Artikel}

FORMULASI ORALLY DISINTERGRATING TABLET (ODT) EKSTRAK ETANOL DAUN KEMANGI (Ocimum americanum L.) DENGAN VARIASI KONSENTRASI EXPLOTAB®

Yulistia Budianti Soemarie; Hayatus Sa'adah, Tri Marginingsih

$1-7$

PDF 
FORMULASI DAN UJI PERTUMBUHAN RAMBUT KELINCI DARI SEDIAAN HAIR TONIC KOMBINASI EKSTRAK DAUN SELEDRI (Apium graveolens Linn) DAN DAUN MANGKOKAN (Polyscias scutellaria (Burm.f.) Fosberg)

Siti Jubaidah; Ria Indriyani, Hayatus Sa'adah, Heri Wijaya

8-14

因 PDF

KARAKTERISTIK INFORMASI TERKAIT CARA PENGGUNAAN METERED-DOSE INHALER DENGAN SPACER YANG MENGANDUNG KOMBINASI BETA-2 AGONIS DAN KORTIKOSTEROID OLEH APOTEKER DI APOTEK WILAYAH SURABAYA TIMUR

Amalia Lorensia; Doddy de Queljoe, Yessica Valensia

$15-27$

因 PDF

GAMBARAN PENGGUNAAN ANTIBIOTIK PADA PASIEN PEDIATRI INFEKSI SALURAN PERNAPASAN AKUT (ISPA) DI KLINIK SINT. CAROLUS BENGKULU

Setya Enti Rikomah, Devi Novia, Septiana Rahma

28-35

㘣 PDF

POTENSI EKSTRAK DAUN TANAMAN KARAMUNTING (Melastoma malabathricum L.) DI DAERAH KALIMANTAN SEBAGAI ANTIBAKTERI Staphylococcus aureus

Rakhmadhan Niah, Riki Nirwan Baharsyah

$36-40$

因 PDF

Uji Validitas Dan Reliabilitas Kuesioner EQ-5D Bahasa Indonesia Untuk Pasien Hemodialisa Gagal Ginjal Kronik

Yugo Susanto, Riza Alfian, Zainur Rahim, Karani Karani

41-47

因 PDF

UJI PERBANDINGAN EFEKTIVITAS ANTIDIABETES EKSTRAK POLISAKARIDA DAN SENYAWA POLIFENOL ALGA COKLAT (Sargassum sp.) PADA MENCIT YANG DIINDUKSI ALOKSAN

Agung Giri Samudra; Fathur Sani K; Moniq Chintama

48-52

因 PDF

Perbaikan Kualitas Hidup Pasien Diabetes Melitus Tipe 2 di RSUD Dr. H. Moch. Ansari Saleh Banjarmasin Dengan Intervensi Brief Counseling

Muhammad Reza Pahlevi, Abdul Rahem, Valentina Metasartika 
因 PDF

FORMULASI DAN UJI EFEKTIVITAS MASKER PEEL OFF PATI JAGUNG (Zea mays sacchrata) SEBAGAI PERAWATAN KULIT WAJAH

Karmilah Karmilah, Nirwati Rusli

$59-66$

因 PDF

EFEK SAMPING OBAT ANTI TUBERKULOSIS (OAT) DAN PENANGANANNYA PADA PASIEN TUBERKULOSIS (TB) DI PUSKESMAS PERUMNAS KOTA KENDARI

Musdalipah Musdalipah; Eny Nurhikma, Karmilah Karmilah, Muh. Fakhrurazi $67-73$

因 PDF

IDENTIFIKASI KANDUNGAN FORMALIN PADA MIE BASAH MENGGUNAKAN PEREAKSI SCHRYVER

Nurul Fatimah, Henny Nurhasnawati, Roufida Zaki

$74-78$

因 PDF

PERBANDINGAN METODE EKSTRAKSI TERHADAP RENDEMEN EKSTRAK DAUN RAMBAI LAUT (Sonneratia caseolaris L. Engl)

Heri Wijaya; Novitasari Novitasari, Siti Jubaidah

79-83

因 PDF

\section{Akreditasi}




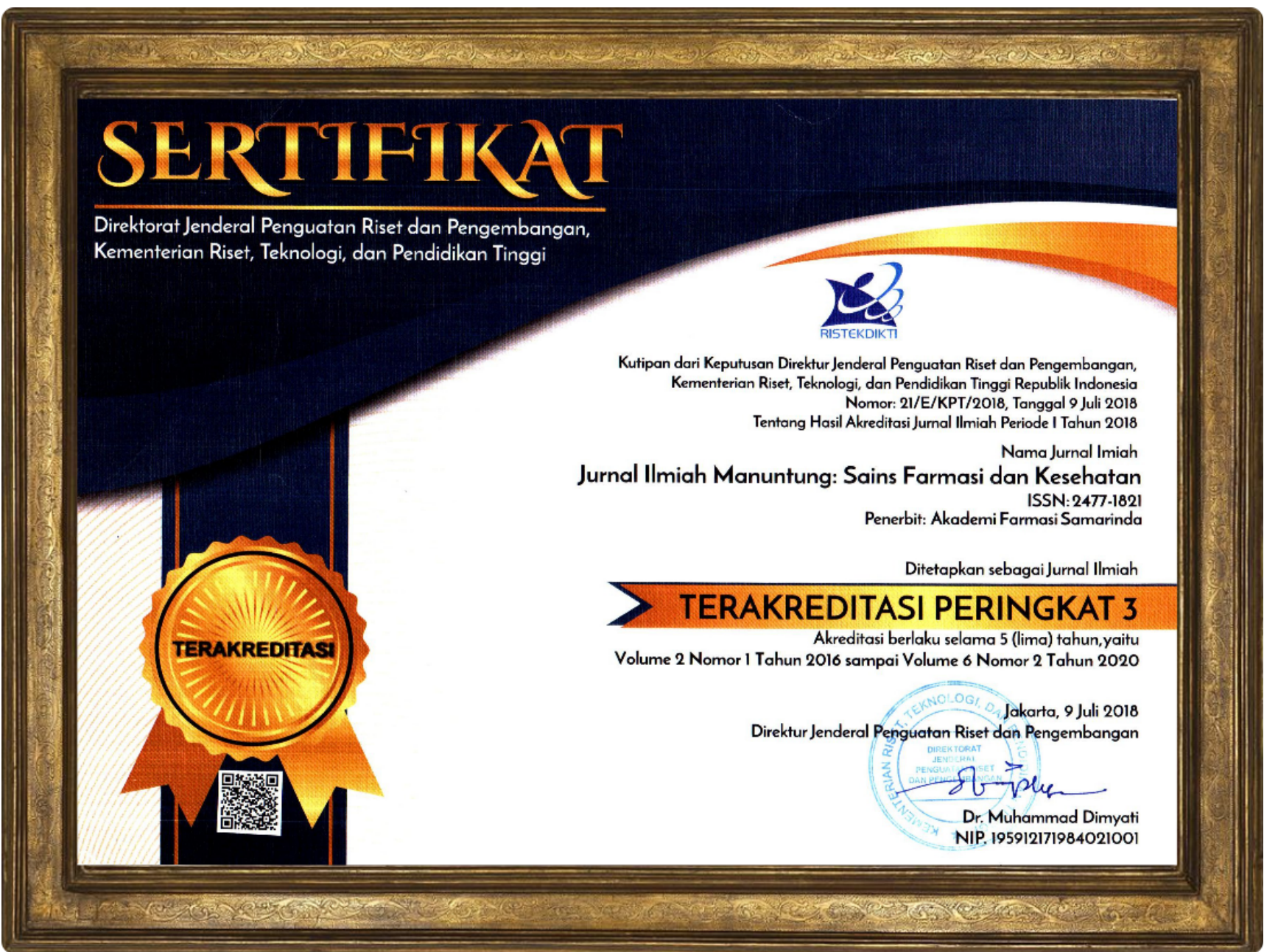

\section{Policies}

\section{Author Charge}

\section{Editorial Team}

\section{Plagiarism Policy}

Open Acces Policy

Digital Archiving

\section{Copyright Notice}

\section{Peer Review Process}

\section{Submit Guidelines}

Template_Journal 


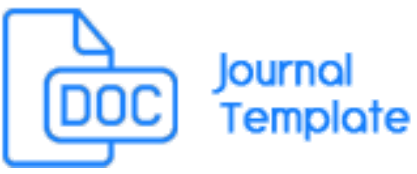

\section{VISITORS}

\section{Visitors

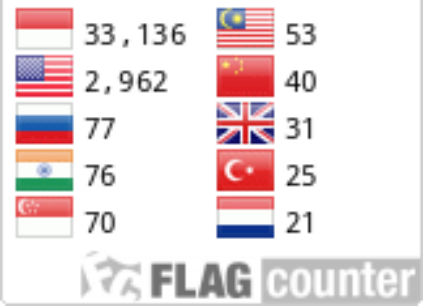

00067731 View My Stats

\section{INDEXED}
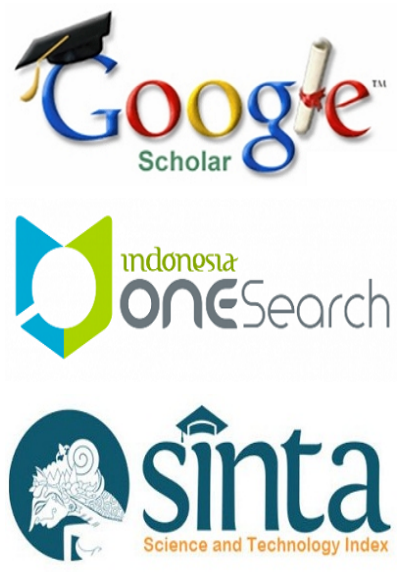

\section{PKPINDEX}

BASE

CA GARUDA

\section{LPPM Akademi Farmasi Samarinda}

Jl. Brig. Jend. Abdul Wahab Sjahranie No. 226, Air Hitam

Samarinda, Kalimantan Timur, Indonesia 
Telp : (0541) 7777363

Email : ejournal.akfarsam@gmail.com

\section{(c) (†) (2)}

This work is licensed under a Creative Commons Attribution-ShareAlike 4.0 International License.

powered by OJS | Open Journal Systems

PKP | PUBLIC KNOWLEDGE PROJECT 